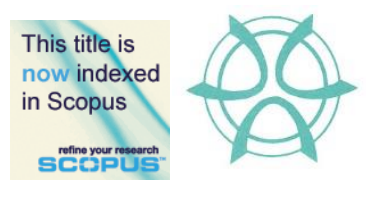

PLANNING MALAYSIA:

Journal of the Malaysian Institute of Planners

VOLUME 16 ISSUE 3 (2018) Page 344 - 356

\title{
ECOLOGICAL FRIENDLY APPLIED TECHNOLOGY TO NEGOTIATE THE DILEMMA BETWEEN ENVIRONMENTAL PROTECTION AND URBAN DEVELOPMENT
}

\author{
Ariva Sugandi Permana ${ }^{1} \&$ Ahmad Nazri Muhamad Ludin ${ }^{2}$
}

Faculty of Built Environment and Surveying

UNIVERSITI TEKNOLOGI MALAYSIA

\begin{abstract}
Urban development consumes resources and therefore abolishes the ecological function of the natural environment. It generates the dilemma between urban development and environmental protection. Urban development cannot be halted for many reasons due to its importance to accommodate population growth, urbanization and economic development. Determinations to negotiate the dilemma between environmental protection and urban development have been undergoing for many years. One of the efforts is mesoscale ecological friendly technology concept where the function of natural environment could be maintained while letting progressive urban development to flourish. The study was conducted in secondary city in Peninsular Malaysia of Johor Bahru. The study was conducted by analysing secondary information obtained from relevant resources, by undertaking internet research on the applications of ecological friendly technology towards sustainability in developed and developing countries, and by observing the connection between urban development and environmental state. The findings show that by employing applied ecological friendly technology, the urban physical development can still be undergoing without substantial environmental impacts.
\end{abstract}

Keywords: ecological friendly technology, environmental protection, urban development, sustainability. 
PLANNING MALAYSIA

Journal of the Malaysia Institute of Planners (2018)

\section{INTRODUCTION}

In a big picture, economic development of many developing countries is depending heavily on natural resources (Barbier, 1987; Panayotou, 1993; Pearce, Barbier, \& Markandya, 2013; Solow, 2016). While natural resources is confined within an environment, economic development attempts to utilize and tends to overuse the natural resources (Gylfason, 2001; Betz, Partridge, Farren, \& Lobao, 2015; Bergstrom \& Randall, 2016), and therefore, environmental conservation and economic development do not always go hand-in-hand, as reflected in a simple illustration in Figure 1.

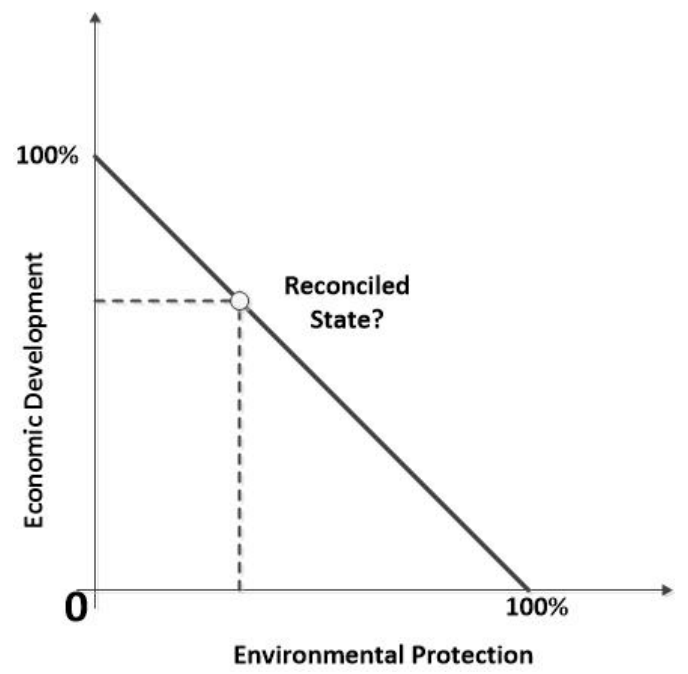

Figure 1: Economic growth vis-à-vis environmental protection

Even though the relationship between economic development and environmental protection does not necessarily linear as exhibited by Figure 1, but it is not wrong to say that the relation can be considered as linear or quasi-linear, as the summation of economic development and environmental protection is actually a binary (Tietenberg \& Lewis, 2016; Shoreman-Ouimet \& Kopnina, 2015). The sum of reconciliation of both aspects leads to 1.0. By this, a negotiation of natural resources use for economic growth and environmental protection towards optimum state would be necessary. The prime question is now to what extent an optimum state is optimum? It could not be answered in a straightforward manner. It depends greatly on many factors such as existing government policy (Sachs, 2015; Susskind \& Ali, 2014), present level of economic development of a country (Tietenberg \& Lewis, 2016), and ethical views of the society on environment (Harper \& Snowden, 2017; Stenmark, 2017). To some extent, environmental protection and economic development is 
Ariva Sugandi Permana \& Ahmad Nazri Muhamad Ludin

Ecological Friendly Applied Technology to Negotiate the Dilemma Between Environmental Protection and Urban

Development

reconcilable towards optimum state. The property rights holder, e.g. the government, can negotiate and reconcile these two entities for better environment and economic development.

Subscribing the analogy of economic development and environmental protection dilemma, in a mesoscale, the dilemma can also be brought to confront the urban development vis-à-vis environmental protection (Carley \& Christie, 2017). The reconciliation, in this case, can be done by letting urban development undergo while keeping the ecological function intact, even though there are physical disturbances on environment. Ecological friendly technology at mesoscale level is recognized in this study as urban environmentalism towards sustainable development (Gibbs, 1998; Mol, Spaargaren, \& Sonnenfeld, 2014; Zhou, 2015).

Biodiversity is an obvious domain that will be impeded first and foremost by urban development. On the other hand, biodiversity is recognized as a keystone of whether or not an ecological entity is healthy (Laurila-Pant, Lehikonen, Uusitalo, \& Venerjarvi, 2015). Extensive and massive land conversion for urban development will definitely promote ecological loss (Chen, Liu, \& Lu, 2016; Appiah, Forkuo, \& Bugri, 2015). However, this study does not give the emphasis on ecological losses i.e. plant and animal losses and ecological footprint, since the land conversion considered in this study was only clustered and small-scale instead of extended and massive land conversion. Rather, it gives the emphasis on physical consequences of the ecological changes that took place due to urban development.

This study looks at the relevant elements of urban development and environmental design which are able to reconcile the physical development of a city and its ecological function by minimizing the disturbance to the function of environment. For the purpose of the study, in-depth field observation and gathering the qualitative secondary information have been done in Johor Bahru, Malaysia. Review of relevant literatures and reports has also been carried out.

\section{THE STUDY AREA}

Johor Bahru, as exhibited in Figure 1, is a city in the southern part of Peninsula Malaysia with about 497,000 total population. Johor Bahru is included in Iskandar Malaysia Region, which is a growth centre in the Southern Peninsula Malaysia. Iskandar Malaysia, itself as a growth centre, is strategically situated in the southernmost tip of Peninsular Malaysia. Iskandar Malaysia upholds a strong identity and advanced economic potential as the region possesses strategic location, which is favourable for ancient traders and merchants from around the globe. 
PLANNING MALAYSIA

Journal of the Malaysia Institute of Planners (2018)

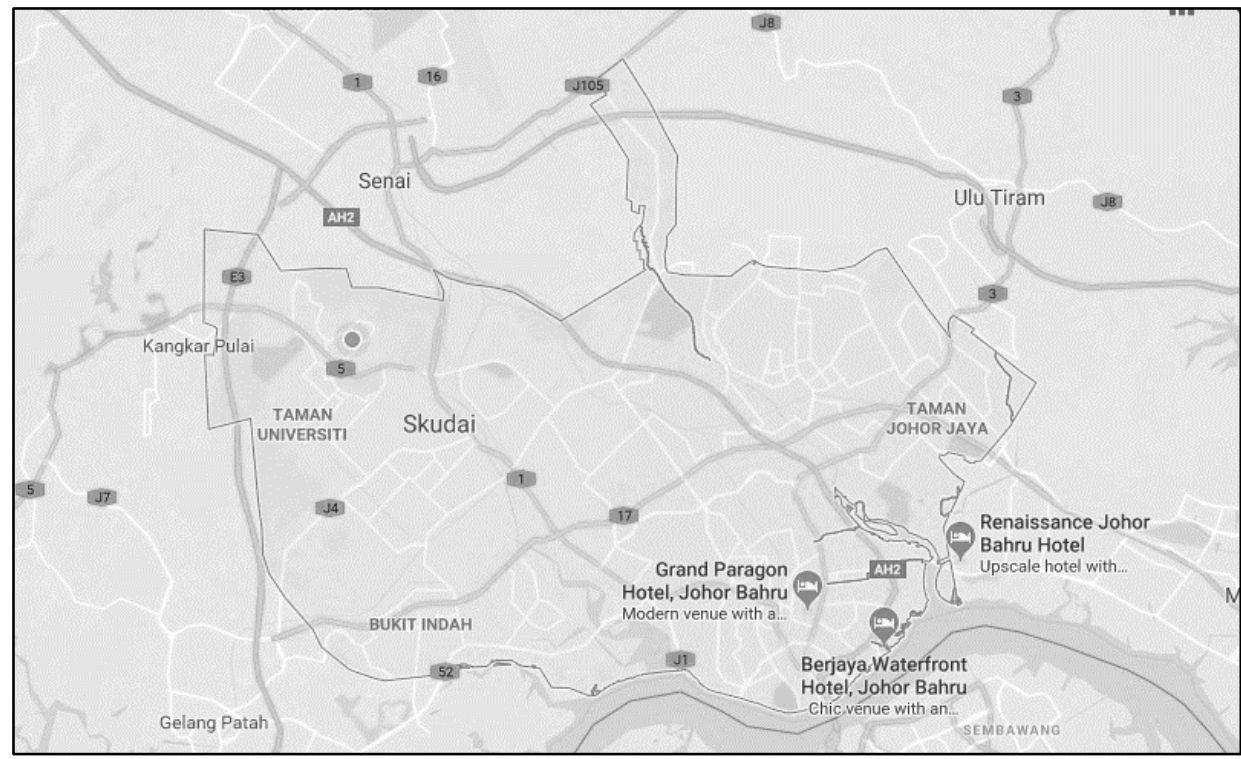

Figure 1: Johor Bahru, Malaysia

Rapid urban development in Johor Bahru was signified by the development of well-planned residential and commercial areas and other builtenvironment elements by employing the principles of acceptable standard environmental and landscape design principles. However, the increase of built environment automatically stalemates the presence of natural environment that carries values beyond merely economic. Moreover, built environment can still deliver the ecological function at some points, if it was designed through the urban environmental or ecological modernization principles.

\section{THE APPROACHES}

This study observes the physical changes as a result of urban development and its physical consequences particularly with respect to hydrological aspect. The study also looks at underlying theoretical groundwork on ecological loss and gain. However, since the area involved in the ecological changes commonly covers very minor change as $S \propto A^{z}$ (Lennon, Kunin, \& Hartely, 2002), where $S$ is number of Species and A is area, and the plants diminished would not impede ecological losses as they are abundance and usually endemics, therefore the quantity of ecological loss would be trivial and thus ignored. 
Ariva Sugandi Permana \& Ahmad Nazri Muhamad Ludin

Ecological Friendly Applied Technology to Negotiate the Dilemma Between Environmental Protection and Urban

Development

\section{Changing in Rainfall-Runoff Relationship: The Most Visible Impacts of Urban Development}

\section{Surface Runoff Modification}

Changes in the imperviousness of the land exert essential influence on rainfallrunoff relationship due to changes in the hydrological-ecological process in urban area (Yao, Wei, \& Chen, 2016). They asserted that the growth of impervious surfaces in urban areas is directly associated with urban development. The factor that influences the variations in urban hydrology includes increased runoff, decreased recession time, decreased groundwater recharge and decreased base flow (Burns et al., 2005; Liu, Ahiablame, Bralts, \& Engel, 2015).

A study in Johor Bahru Malaysia by Majid, Jamaludin and Ibrahim (2013) shows a linear model on the correlation between housing density and impervious surface that can be expressed by an equation of $\ln \{y /(1-$ y) $\}=0.6716+0.08 \mathrm{x}$, where $\mathrm{y}$ : proportion of impervious surface and $\mathrm{x}$ : housing density (unit/acre). By using this equation, the correlation between housing density in unit/acre and percentage of impervious ground surface is shown in Figure 2.

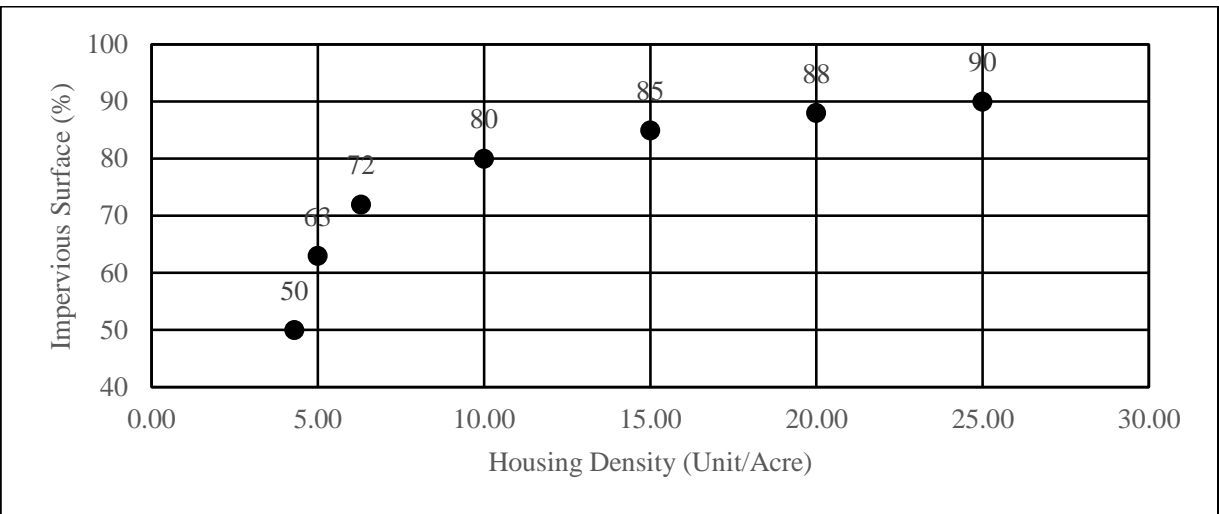

Figure 2: Housing density and impervious surface Source: Adapted from Majid et al. (2013)

Figure 2 reflects residential plots in Johor Bahru with bungalows and Semi-Ds type of house, where the ground surface composed of pavement and roof in a flat land, and unimproved area. It is obvious that the higher housing density would result in higher impervious area, and therefore higher surface runoff as exhibited in Figure 3. 
PLANNING MALAYSIA

Journal of the Malaysia Institute of Planners (2018)

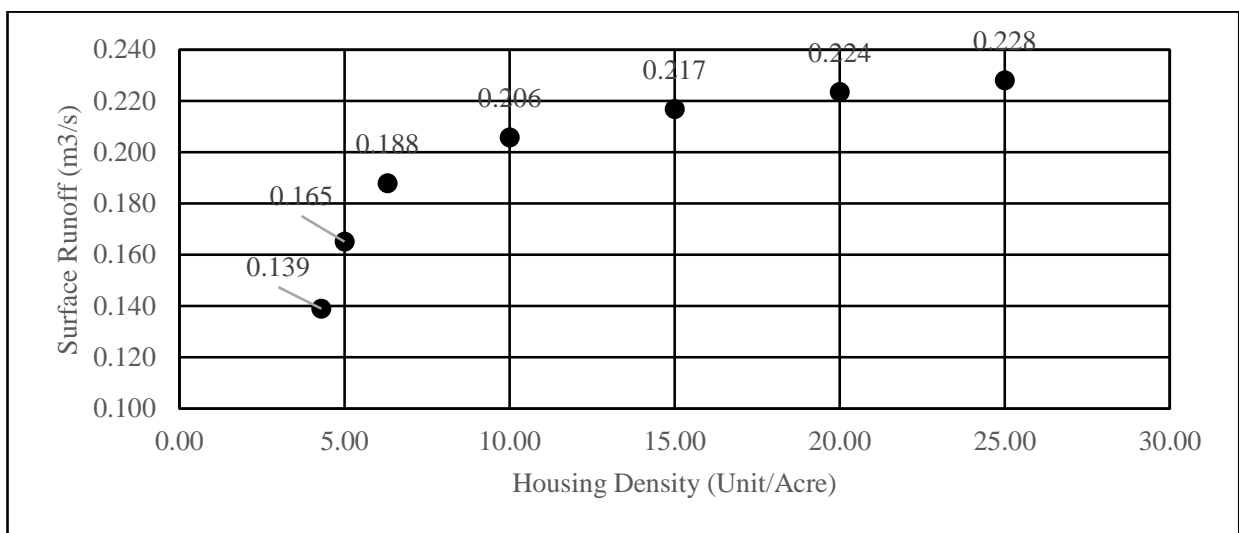

Figure 3: Housing density and surface runoff, for $\mathrm{I}=1 \mathrm{~mm} / \mathrm{hour}, \mathrm{A}=1 \mathrm{~km}^{2}$

Figure 3 confirms that changing the landscape from natural environment to built environment would subsequently increase the possibility of getting urban flooding. This situation should be optimized by letting residential development takes place - because the development is unavoidable in a growing city - and at the same time minimize the possibility of flood occurrence. The coping strategies to optimize this dilemma are discussed in the subsequent sections.

\section{Underground Storage}

As discussed in the earlier section, floods are greatly influenced by urban land use. Not many local authorities can appropriately control land use in order to reduce flood magnitude. Given the present run-off coefficients are not easy to modify and also rainfall is beyond people's control, thus the maximum discharge from an urban area theoretically cannot be modified. However, the rate of release of discharge can be modified through natural storage. This concept works significantly under one condition: that the efforts must be done by all individual citizens. The individuals provide storage according to their land plot area, defined by $S_{i}=0.001 A_{i} \times h \times D$, where $S_{i}$ is storage that must be provided individually $\left(\mathrm{m}^{3}\right)$, Ai is individual land plots area $\left(\mathrm{m}^{2}\right), \boldsymbol{h}$ is design rainfall $(\mathrm{mm} /$ hour$)$ determined by the local authority, and $\boldsymbol{D}$ is projected rainfall duration (hour). The best situation will be created if those storages are installed underground since this storage enables collected rainfall to recharge into groundwater. In the long run, it will provide sufficient groundwater source and ultimately lead to sustainable development. Rain water that falls within an individual land parcel is collected, including through pipes from the roof-top, and discharged into an underground tank for subsequent recharge into groundwater (Figure 4). 
Ariva Sugandi Permana \& Ahmad Nazri Muhamad Ludin

Ecological Friendly Applied Technology to Negotiate the Dilemma Between Environmental Protection and Urban Development

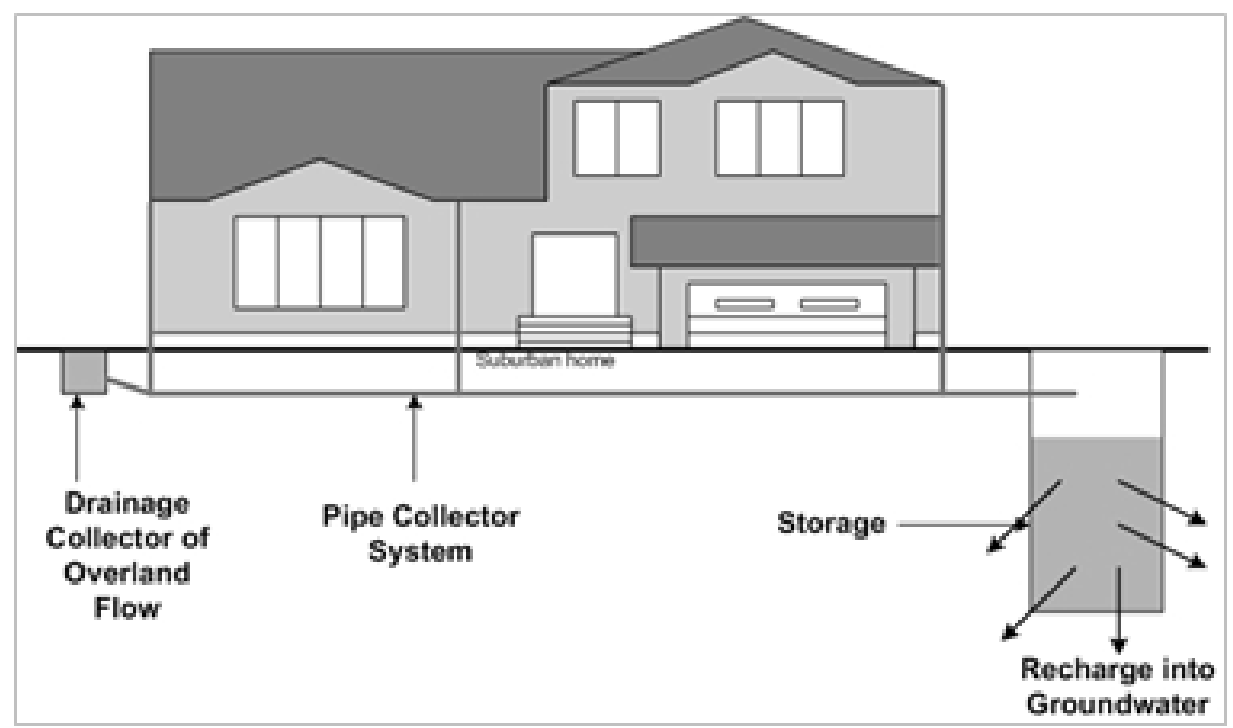

Figure 4: Individual underground rainwater storage system

The effectiveness of the individual storage system depends on the hydraulic conductivity of tank storage, groundwater table, as well as rainfall intensity, duration and frequency. More permeable soil structure around the storage boosts groundwater recharge, therefore, the process of emptying the storage will be faster, and successive rainfall can be stored properly in the tank. Higher groundwater table and less permeable soil structure will delay the emptying process of the tank and reduces its capacity for storing successive rainfall.

In densely populated urban area, where detached individual houses are normally rare, and multi-storey building types are dominant, the storage system can be placed at either roof-top or basement (Figure 5). However different operation is applied for the roof-top storage, that is, at the time when rainfall stops, and underground storage is empty, the roof-top storage can then be released to the underground storage. The same principle of storage calculation for individual detached houses can be applied to multi-story buildings. With this arrangement, assuming that individual storage system works well, the reduction of flood magnitude will be directly proportionate to the built-up area excluding roads and other non-occupancy areas. This reduction also leads to a reduction in the need for drainage infrastructure; costs for providing such infrastructure; and flood damages and losses. At the same time, it potentially leads to an increase in groundwater resources and improved environmental sustainability. 


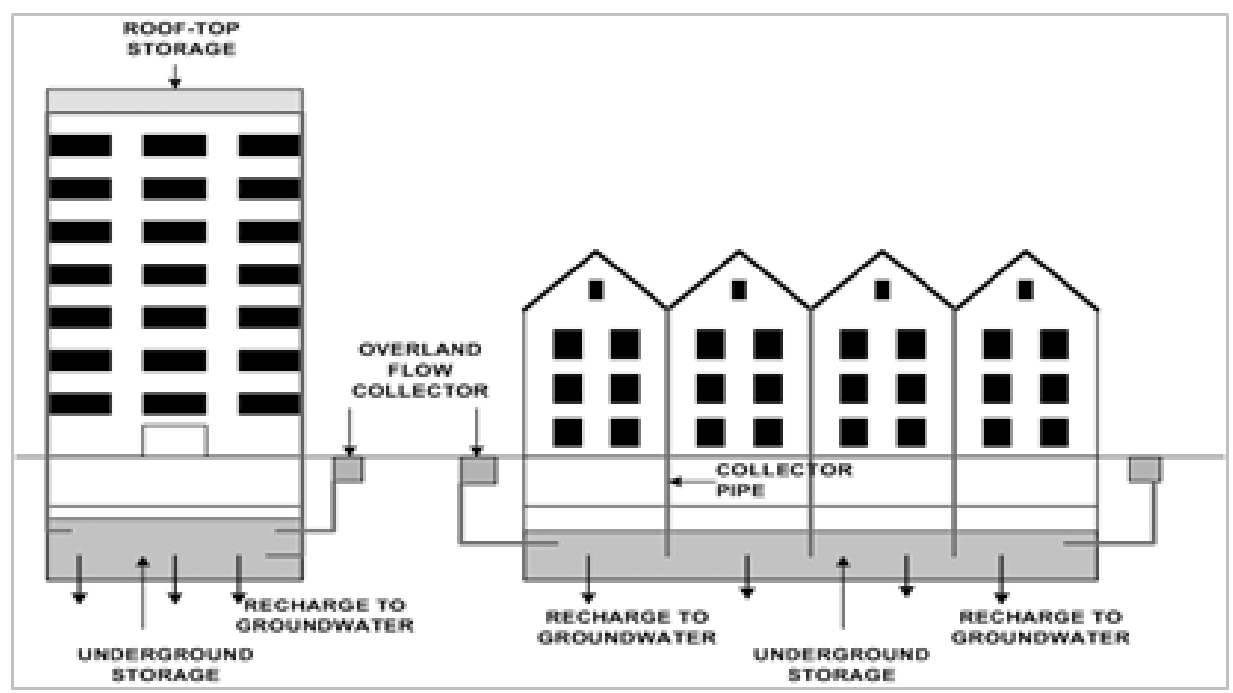

Figure 5: Storage system in urban-type residential building

If all the above-mentioned activities are implemented appropriately, harmonious coexistence between human and nature will be potentially achieved, and urban development will not badly affect urban environment. Floods will no longer be viewed as disasters to defend against, but rather as normal, natural phenomena that humans must learn to adapt to and make the best of. The Netherlands' socially-rooted approach for addressing climate change adaptation to flooding sums it up best with a vision of a country "safe against flooding, while still remaining an attractive place to live, to reside and work, for recreation and investment" (Wenger, Hussey, \& Pittock, 2013).

\section{Pervious Interlocking Paver}

The most obvious and visible demand of an urbanizing area to cope with increasing car ownership and commercial area is parking lots. The acreage for parking lots depend on some factors that will contribute to the number of parking spaces that will be available on an acre of land. This includes: (a) Size of each parking space (b) Size and design of driving and turning lanes (c) Layout and topography of the land (d) Other factors such as handicap-accessible parking and surface of the lot/field. In case the demand of parking lots must be met by means of outdoor off-street parking, the land conversion from vacant land to parking lots will be necessary. If the conversion took place from bare land, the biodiversity losses, e.g. plants losses, would not be significant, and also many endemic plants in the Peninsular Malaysia are currently either not at vulnerable or endangered status, rather at 'least concern' (IUCN, 2017). By this status, the endemic plant losses as a result of changing landscape would be insubstantial, and therefore other factor, i.e. urban flood, would be more concern. 
Ariva Sugandi Permana \& Ahmad Nazri Muhamad Ludin

Ecological Friendly Applied Technology to Negotiate the Dilemma Between Environmental Protection and Urban Development

Sometimes we need to construct a parking lots (a built environment) from previously natural environment by minimizing the environmental function of the area, i.e. keeping surface runoff at minimum level while maintaining the natural environment and beauty. In such cases, the natural beauty can be improved by artificial natural beauty as more preferred by people due to non-random appearance, e.g. theme parks are more preferable than random nature. At the same time, surface runoff can be reduced by adopting pervious interlocking paver. In this case, ground surface is designed to allow as much as possible infiltration rate of surface runoff, as exhibited in Figure 6. The use of pervious pavers may reduce surface runoff around $10-15 \%$. This is a somewhat significant in the reduction of flood. Other than reducing surface runoff and flood, mesoscale urban environmentalism practices can also reduce or eliminate epidemic diseases.
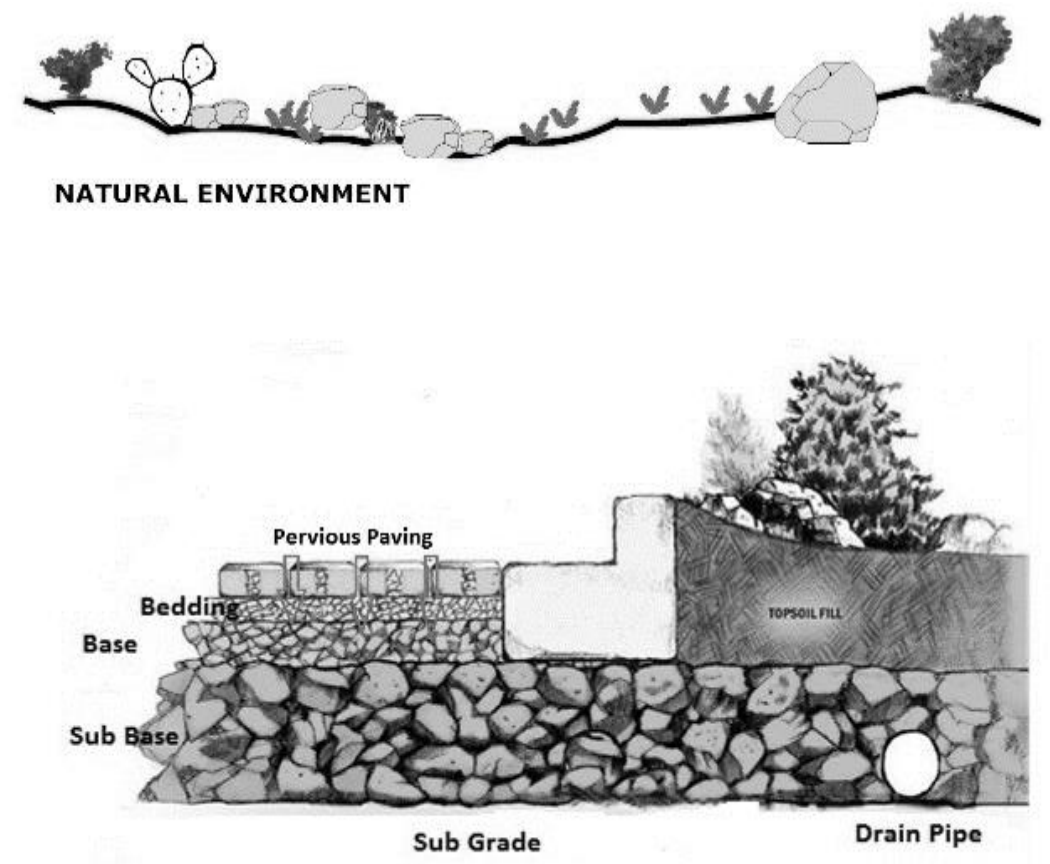

BUILT ENVIRONMENT

Figure 6: Allowing surface runoff to recede

\section{Eliminating Prevalent Disease}

Some parts of Johor Bahru are dengue fever prevalent as many cases of this disease spread by Aedes Aegypti were found in the areas. One of the causes is due to random natural condition of the place that encourages mosquitoes to breed. At this random condition, stagnant storm water could not freely flow and therefore land surface could not totally dry up. This situation invites mosquitoes to breed. 
PLANNING MALAYSIA

Journal of the Malaysia Institute of Planners (2018)

Figure 7 exhibits a situation that in natural condition, the surface runoff would generate a long-term inundation i.e. stagnant water, which along with dead shrubs and plants, create a perfect breeding grounds for Aedes Aegypti that causes dengue fever. In some residential neighbourhoods in Johor Bahru, the Aedes Aegypti breading grounds were augmented by lack of awareness of some citizens in littering and disposing trashes. It makes some residential neighbourhoods become endemic areas where dengue becomes prevalent. An urban environmentalism approach can be applied by eliminating the culprit, i.e. the breeding grounds of the mosquitoes. In this case, the natural condition can be improved by providing a sufficient drain pipe with sand and gravel filter. Thus, during rainy days, the storm water would quickly be absorbed by drainage pipe, and no inundation is created afterwards, eliminating Aedes aegypti breeding ground. At the same time, the environmental function at that place will be maintained i.e. natural environment is still unharmed. There would be a few ecological losses at the area for sure, but the lost can commonly be offset somewhere else.
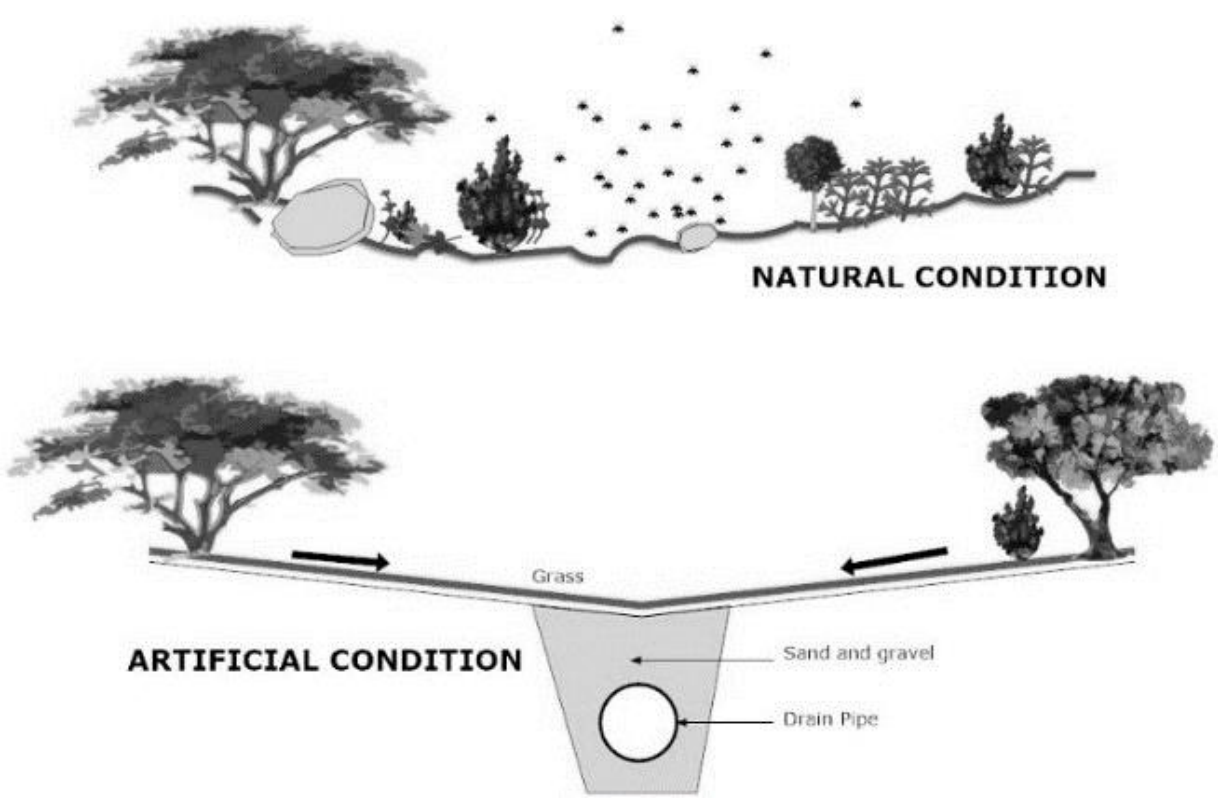

Figure 7: Eliminating aedes aegypti breeding grounds

\section{Connecting Habitats}

In urban area or anywhere where the road construction must separate one habitat into two, an ecological tunnel would be necessary. There are two different definitions on ecological tunnel from geological and ecological viewpoints. From the geological viewpoint, an ecological tunnel is an environmental friendly and 
Ariva Sugandi Permana \& Ahmad Nazri Muhamad Ludin

Ecological Friendly Applied Technology to Negotiate the Dilemma Between Environmental Protection and Urban

Development

energy-efficient state of during and post-construction phase (Zhang, Lei, \& Xue, 2011). On the other hand, from the ecological standpoint, an ecological tunnel is defined as a tunnel that is able to convey both human and animal activities without creating disturbance to both species (WWF Russia, 2018). However, this study subscribes to the latter definition.
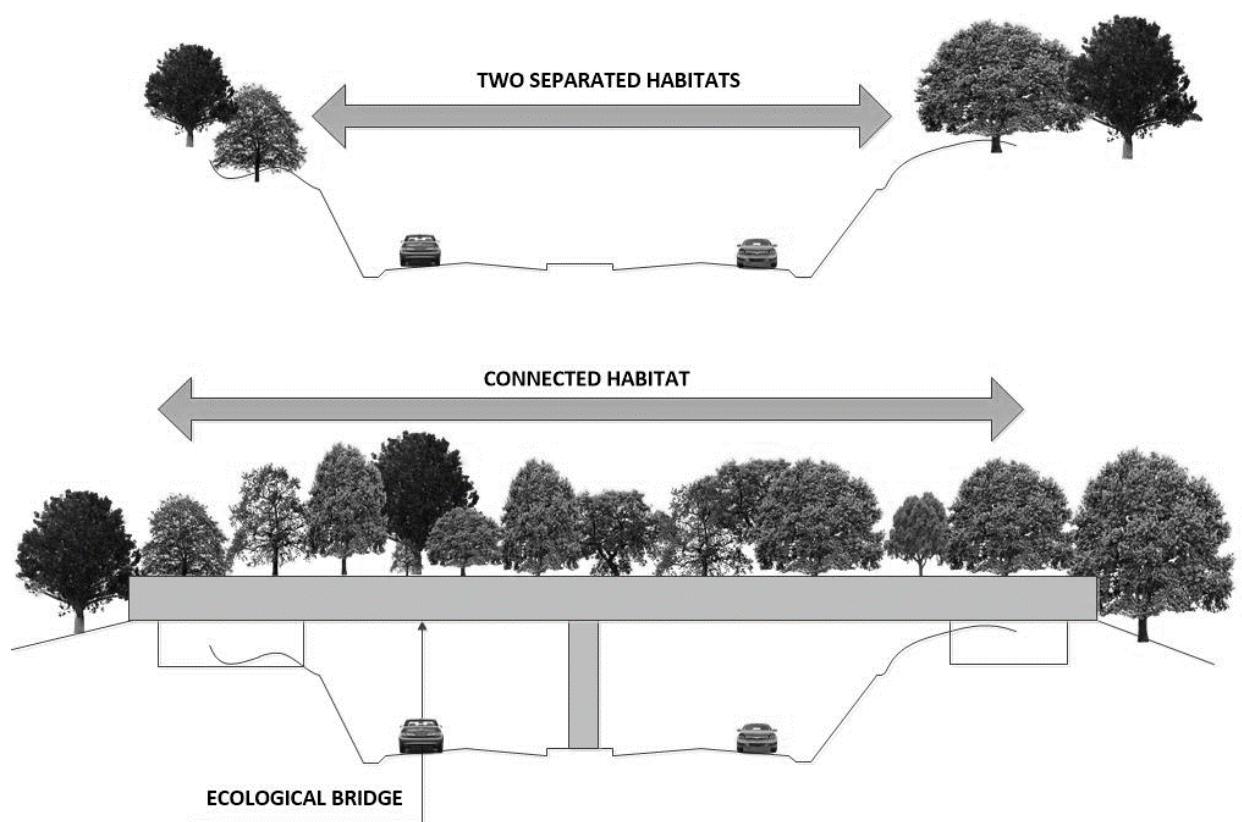

Figure 9: A separated and re-connected habitat

An ecological tunnel or ecological bridge or ecological link is an equivalent system of a fish ladder in the dam construction where a habitat is separated by the dam. A fish ladder is a right riposte to reconnect the habitat separated by anthropogenic activities like dam, particularly for seasonally migrating fish. This is an effort to reconcile the cohabitation of man and nature. The disturbance of human activities would be minimized with the presence of ecological link.

\section{WAY FORWARD}

Negotiation between urban development and environmental protection can be done in many ways. One of the ways is through ecologically friendly technology, as demonstrated by some good practices in the study area, through the discussion above. To expedite the adoption of ecological friendly technology by local authorities, mainstreaming the ecologically friendly technology in planning policies and tools is necessary along with consistent and persistent law enforcement for appropriate reconciliation process from micro to macro level. By 
this action, the disturbance to biodiversity, ecological integrity and environmental disasters, such as urban flood, could be avoided or minimized. At the same time, urban development could be undertaken without very much worry about ecological disruption, because the development envisions beyond the planning horizons.

\section{REFERENCES}

Appiah, D. O., Forkuo, E. K., \& Bugri, J. T. (2015). Land use conversion probabilities in a peri-urban district of Ghana. Chinese Journal of Urban and Environmental Studies, 3(03), 1550026.

Barbier, E. B. (1987). The concept of sustainable economic development. Environmental conservation, 14(2), 101-110.

Bergstrom, J. C., \& Randall, A. (2016). Resource economics: An economic approach to natural resource and environmental policy. Cheltenham, UK: Edward Elgar Publishing.

Betz, M. R., Partridge, M. D., Farren, M., \& Lobao, L. (2015). Coal mining, economic development, and the natural resources curse. Energy Economics, 50, 105-116.

Burns, D., Vitvar, T., McDonnell, J., Hassett, J., Duncan, J., \& Kendall, C. (2005). Effects of suburban development on runoff generation in the Croton River basin, New York, USA. Journal of Hydrology, 31, 266-281.

Carley, M., \& Christie, I. (2017). Managing sustainable development. London: Routledge.

Chen, M., Liu, W., \& Lu, D. (2016). Challenges and the way forward in China's newtype urbanization. Land Use Policy, 55, 334-339.

Gibbs, D. (1998, November). Ecological Modernization: A Basis for Regional Development? Seventh International Conference of Greening Industry Network. Partnership and Leadership: Building Alliance for Sustainable Future. November 15-18, 1998, Rome, Italy.

Gylfason, T. (2001). Natural resources, education, and economic development. European Economic Review, 45(4-6), 847-859.

Harper, C., \& Snowden, M. (2017). Environment and society: Human perspectives on environmental issues. London: Routledge.

IUCN (2017). The red list of threatened species (Version 2017-3). Available at http://www.iucnredlist.org/.

Laurila-Pant, M., Lehikonen, A., Uusitalo, L., \& Venerjarvi, R. (2015) How to value biodiversity in environmental management? Ecological Indicators, 55, 1-11.

Liu, Y., Ahiablame, L. M., Bralts, V. F., \& Engel, B. A. (2015). Enhancing a rainfallrunoff model to assess the impacts of BMPs and LID practices on storm runoff. Journal of Environmental Management, 147, 12-23.

Lennon, J. J., Kunin, W. E., \& Hartely, S. (2002). Fractal species distributions do not produce power-law species-area relationships. Oikos, 97, 378-386.

Majid, M. R., Jamaludin, J. A. \& Ibrahim, W. Y. W. (2013). Estimation of residential impervious surface using GIS technique. Planning Malaysia Journal, 2, 23-38.

Mol, A. P., Spaargaren, G., \& Sonnenfeld, D. A. (2014). Ecological modernization theory: Taking stock, moving forward. In S. Lockie, D. A. Sonnenfeld, \& D. R. 
Ariva Sugandi Permana \& Ahmad Nazri Muhamad Ludin

Ecological Friendly Applied Technology to Negotiate the Dilemma Between Environmental Protection and Urban

Development

Fisher, Routledge international handbook of social and environmental change (pp. 15-30). London: Routledge.

Panayotou, T. (1993). Empirical tests and policy analysis of environmental degradation at different stages of economic development. Geneva: International Labour Office.

Pearce, D., Barbier, E., \& Markandya, A. (2013). Sustainable development: economics and environment in the Third World. Routledge.

Sachs, W. (2015). Planet dialectics: Explorations in environment and development. London: Zed Books Ltd..

Shoreman-Ouimet, E., \& Kopnina, H. (2015). Reconciling ecological and social justice to promote biodiversity conservation. Biological Conservation, 184, 320-326.

Solow, R. M. (2016). Resources and economic growth. The American Economist, 61(1), $52-60$.

Stenmark, M. (2017). Environmental ethics and policy-making. Londn: Routledge.

Susskind, L. E., \& Ali, S. H. (2014). Environmental diplomacy: Negotiating more effective global agreements. Oxford: Oxford University Press.

Tietenberg, T. H., \& Lewis, L. (2016). Environmental and natural resource economics. (n.p.): Routledge.

Wenger, C., Hussey, K., \& Pittock, J. (2013). Living with floods: Key lessons from Australia and abroad, National Climate Change Adaptation Research Facility, Gold Coast.

WWF Russia (2018). Ecological tunnel for people and leopards is opened in Russia Retrieved from https://wwf.ru/en/resources/news/bioraznoobrazie/narvinskiytonnel-otkryt-v-primore-na-blago-lyudey-i-leopardov/.

Yao, L., Wei, W., \& Chen, L. (2016). How does imperviousness impact the urban rainfallrunoff process under various storm cases? Ecological Indicators, 60, 893-905.

Zhang, Z., Lei, Q., \& Xue, Q. (2011). Ecological tunnel for the 21st century: A new conception and methodology. Journal of Transportation Technologies, 1, 54-57.

Zhou, Y. (2015). State power and environmental initiatives in China: Analyzing China's green building program through an ecological modernization perspective. Geoforum, $61,1-12$. 